\title{
O Papel da Comunicação na Elicitação de Requisitos - Entrevistas e Brainstorming
}

\author{
The Role of Communication in Requirements Elicitation - Interviews and Brainstorming
}

Hugo Felipe Dias da Costa ${ }^{1}$

\section{João Henrique Correia Pimentel ${ }^{2}$ (B) http://orcid.org/0000-0002-7441-0796}

\footnotetext{
${ }^{1}$ Escola Politécnica de Pernambuco, Universidade de Pernambuco, Recife, Brasil,

2 Universidade Federal Rural de Pernambuco, Cabo de Santo Agostinho, Brasil

E-mail do autor principal: Hugo Felipe hugofdias7@gmail.com
}

\section{Resumo}

Este trabalho tem como objetivo compreender a forma como as técnicas e os conceitos de comunicação podem auxiliar a elicitação de requisitos, na área de Engenharia de Software. A elicitação de requisitos é de extrema importância para o desenvolvimento do software, permitindo a compreensão do problema a ser resolvido. Em particular, são analisadas duas técnicas de elicitação: Entrevista e Brainstorming. Este estudo parte da premissa de que a comunicação é uma etapa crucial para o sucesso da elicitação e que os elementos da comunicação - em particular a fala e a audição - são fatores que influenciam a coleta de informações sobre os requisitos dos stakeholders pelos engenheiros de requisitos.

Palavras-Chave: Engenharia de Software; Engenharia de Requisitos; Elicitação de Requisitos; Técnicas de Elicitação; Comunicação; .

\begin{abstract}
This work aims to investigate how the techniques and concepts of communication may assist in requirements elicitation, in the area of Software Engineering. Requirements elicitation is of extreme importance in the context of software development, allowing to understand the problem being addressed. In particular, two elicitation techniques are analyzed: Interview and Brainstorming. This study starts from the hypothesis that communication is a crucial step for the success of requirements elicitation and that the elements of communication - in particular speaking and listening - are factors that influence the gathering of information about the stakeholders' requirements by requirements engineers.
\end{abstract}

Key-words: Keywords: Software Engineering; Requirements Engineering; Requirements Elicitation; Elicitation Techniques; Communication. 


\section{Introdução}

O número de tarefas executadas pelas pessoas em relação ao tempo é geralmente grande e demanda muito trabalho. Daí surge a ideia de automatizar essas tarefas criando um software que facilite o trabalho e consequentemente reduza o tempo. O software facilita a comunicação entre a máquina e o homem, com finalidade de dirigir na tomada de decisão nos negócios e no cotidiano, proporcionando soluções para problemas dos mais variados, segundo De Souza Rodrigues [1]. Para criar estes softwares precisa-se entender a necessidade do cliente e atender as suas expectativas.

Na construção de um software é necessário a execução de tarefas fundamentais e indispensáveis para extrair as informações do cliente, a fim de levantar requisitos essenciais, aqueles que dizem respeito às principais propriedades que darão a estrutura inicial para desenvolver o software. Segundo Silva [2], a elicitação de requisitos é a compreensão das necessidades e expectativas esperadas do sistema levantados pelo o usuário, junto ao engenheiro de requisitos, e se faz necessário que seja tratada com grande importância.

Belgamo [3] afirma que o engenheiro de requisitos, para extrair os requisitos para o desenvolvimento do software, encontrará diversas dificuldades, tais como: o usuário não saber efetivamente o que ele quer e dificuldades de comunicação entre usuário e desenvolvedor. Para auxiliar nesta atividade, o engenheiro requer uma boa comunicação através da execução de técnicas de elicitação: entrevistas, reuniões em grupo, entre outras, junto às pessoas envolvidas, que irão contribuir para a otimização do projeto, chamados de stakeholders.

Caso existam barreiras que interfiram nesta comunicação a qualidade do software poderá não ser satisfatória, havendo divergências na elaboração do projeto para o cliente, bem como retrabalho e perda de tempo no desenvolvimento do projeto. De acordo com Belgamo [3], desde o início do projeto muitos problemas podem ser observados, tais como: a possível escolha errada dos entrevistados, especificações incorretas dos requisitos ou mesmo dificuldade de comunicação devido às diferentes personalidades, pois aspectos sociais interferem na elicitação dos requisitos. Estes problemas, se não cuidados, podem levar o usuário a não estar satisfeito com o resultado do projeto.

De acordo com Chiavenato [4], a comunicação é indispensável para a elicitação dos requisitos, mas nem todos estão aptos ou são capazes de criar o tipo de ambiente de trabalho rico em informações, pois isto demanda ouvidos atentos, e preparo para entender a linguagem para além das palavras. Apesar dos progressos da tecnologia da informação e da comunicação, esta entre as pessoas ainda deixa muito a desejar. Isso ocorre visto que a mesma não depende apenas da tecnologia, mas sim do convívio interpessoal e da compreensão da linguagem dentro do contexto de uso, um processo caracterizado por ser dinâmico.

Algumas equipes de desenvolvimento de software erram ao não dedicar tempo suficiente para entender, interpretar, extrair e registrar do cliente o que ele realmente precisa. A comunicação é intrínseca a essas atividades, seja entre a equipe e outros stakeholders (como clientes e usuários) ou seja internamente (entre engenheiros de requisitos, gerentes, desenvolvedores, etc.).

A comunicação é importante não apenas durante a elicitação de requisitos, mas também durante todas as fases do projeto. Por falta de uma comunicação apropriada, muitas falhas são cometidas, podendo até mesmo causar transtornos maiores e perda de tempo para a reversão de situações críticas. A Realização desta comunicação requer determinação e organização para auxiliar nas tomadas de decisões do projeto e estimular o comprometimento e a aproximação entre todos os participantes.

Monteiro e Alencar [5] também chamam a atenção para a falta de um gerenciamento adequado das comunicações como uma das principais causas de fracasso em projetos de software. Ainda para esses autores, o objetivo da comunicação eficaz é o seguinte: estabelecer canais que possibilitem 0 relacionamento ágil e transparente, da direção com o público interno e entre os próprios elementos que integram a elicitação.

A comunicação interpessoal, apesar de não ser muito pesquisada nas engenharias, já possui um grande corpo de conhecimento adquirido em áreas como Linguística, Psicologia, Sociologia e Administração, afirma Penteado [6]. Este trabalho tem como objetivo iniciar um conjunto de estudos que permita a aplicação desse conhecimento à Engenharia 
de Software, identificando de que forma as técnicas de comunicação podem auxiliar no processo de Engenharia de Requisitos. Como objetivo específico, neste trabalho analisamos como o conhecimento sobre a audição e a fala pode beneficiar a aplicação de duas técnicas de elicitação de requisitos: Entrevista e Brainstorming.

Este artigo foi estruturado e dividido nas seguintes seções: na seção 2 está descrita a metodologia utilizada. A seção 3 é descrita a comunicação. A seção 4 contém uma visão geral de Engenharia de Requisitos e as técnicas de elicitação selecionadas para este trabalho: entrevista e brainstorming. Na seção 5 são apresentadas as análises das duas técnicas de elicitação escolhidas. Na seção 6 encontram-se a conclusão e trabalhos futuros.

\section{Metodologia}

Esta pesquisa tem ênfase qualitativa e é de tipo bibliográfica. Para o desenvolvimento da pesquisa foi realizada uma consulta no Google Acadêmico e em bibliotecas. Nesta pesquisa foram utilizadas as seguintes palavras-chave: "Engenharia de Requisitos", "elicitação de requisitos", "técnicas da elicitação" e "comunicação". Posteriormente foram consultados trabalhos sobre duas técnicas de elicitação em específico: Entrevista e Brainstorming. Foram considerados os trabalhos cujos resumos tinham relação com o objetivo de pesquisa proposto.

Os resumos dos trabalhos encontrados foram lidos e analisados no sentido de se verificar sua pertinência para o estudo em questão e desconsiderados aqueles que fugiram ao tema proposto. Em seguida foi realizada a leitura e análise dos conteúdos que contribuíam para o objetivo deste trabalho e realizada a composição do presente texto.

As principais fontes de informação sobre comunicação adotadas neste trabalho foram "A Técnica Da Comunicação Humana" [6], "Comportamento Organizacional" [4], e "Introdução à Linguística" [7].

Nas próximas seções será apresentada a fundamentação teórica deste trabalho: inicialmente, uma introdução aos principais co nceitos de comunicação; em seguida, uma visão geral sobre Engenharia de Requisitos, com foco em elicitação.

\section{Comunicação}

Conforme Chiavenato [4], a comunicação pode ser entendida, de forma simples, como a troca de informação entre o emissor e o receptor. Essa troca é realizada através de um meio de transmissão de uma pessoa para outra, em que o emissor tem o dever de transmitir a informação de forma clara e coerente para que o receptor possa interpretá-la e compreendê-la.

O processo de comunicação é um mecanismo de reciprocidade e implica na troca de sinais com intenção de enviar e compreender a mensagem entre duas ou mais pessoas.

No processo comunicacional é de suma importância a atenção aos mínimos detalhes, para reduzir ao máximo os fatores que provocam ruído e que, consequentemente, podem alterar ou interferir em toda a comunicação. Nesse sentido, é importante observar não apenas a linguagem verbal (uso da fala ou escrita), como também a linguagem não verbal (uso de figuras, imagens, símbolos, postura corporal e gestos).

A comunicação se desenvolve a partir de alguns elementos, quais sejam: fonte, codificação, canal, decodificação, receptor e retroação (Figura 1 ). O ruído pode se apresentar em quaisquer destes, prejudicando o processo comunicacional. Cumpre ressaltar que, para que a comunicação possa ocorrer de maneira eficaz, cada um dos aspectos explicitados deve funcionar corretamente. A seguir, apresentamos a definição dos elementos que compõem a comunicação, de acordo com Chiavenato [4].

Fonte: É responsável por transmitir a mensagem, quem (Fonte) está comunicando a quem (Receptor). Também chamada de Emissor. Na comunicação existe uma fonte, uma pessoa ou grupo, com intuito de

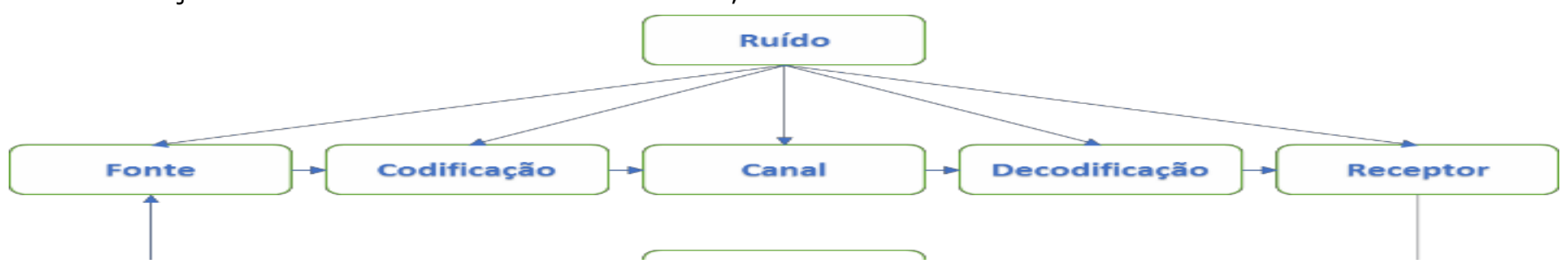

Figura 1: Esquema do processo da comunicação. Adaptado[14]. 


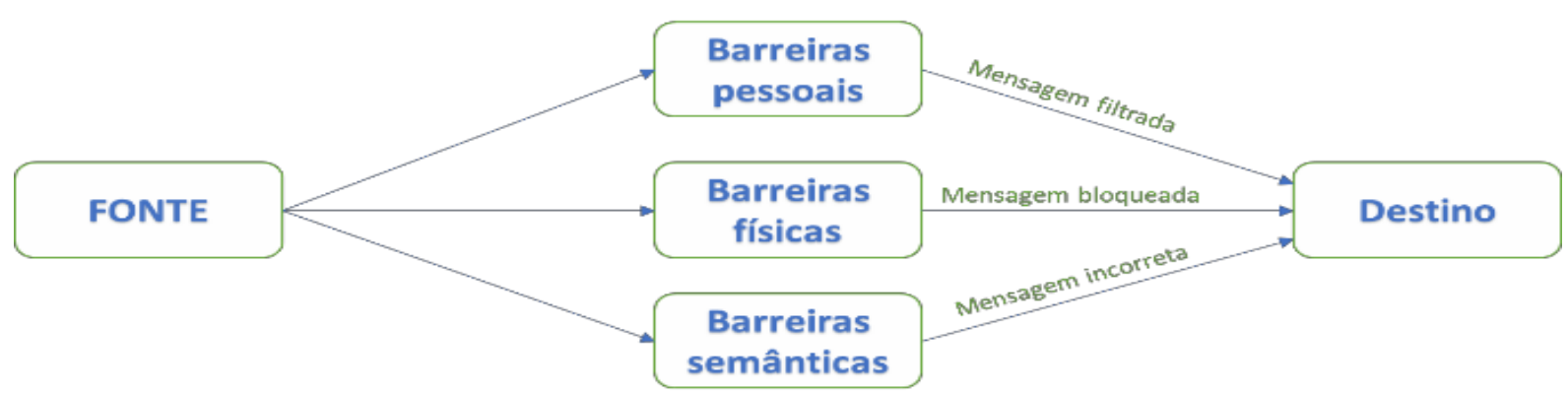

Figura 2: Como funcionam as barreiras à comunicação. Adaptado[14].

empenhar-se para codificar a mensagem, a fim de comunicar-se com o destino final, o receptor.

Codificação: Para que a transmissão da mensagem seja realizada, é necessário que seus símbolos sejam traduzidos de uma maneira que possa ser enviada adequadamente através do canal. Alguém que domina a linguagem é capaz de usá-la como ferramenta para esclarecer a mensagem.

Canal: É o meio responsável pela transmissão da mensagem, escolhida pelo emissor. Pode ser de forma eletrônica, impressa, com a própria voz, ou até mesmo não-verbal, utilizando gestos.

Decodificação: Este processo é responsável por traduzir e interpretar a mensagem para o receptor enviada pelo emissor. Quando uma pessoa detém conhecimento da linguagem usada é capaz de compreender o que está nas entrelinhas.

Receptor: É a pessoa ou grupo a quem a mensagem foi dirigida. Também chamado de destino final.

Retroação: Conhecido também por feedback. O receptor verifica se houve sucesso da mensagem recebida e se sua compreensão foi alcançada ou não.

Ruído: São os elementos que podem interferir na mensagem, reduzindo ou invalidando a efetividade. 0 ruído pode estar presente em quaisquer das fases do processo de comunicação, por exemplo: impaciência e barulhos externos.

Nas subseções a seguir são apresentadas as principais barreiras na comunicação e algumas técnicas que podem ser aplicadas para melhorá-la, além de uma breve discussão sobre possibilidades de treinamento para o desenvolvimento da capacidade comunicativa.

\subsection{Barreiras na comunicação}

É notório que falhas na comunicação podem ser responsáveis por boa parte do insucesso, das perdas, dos prejuízos, atrasos e retrabalhos no processo de desenvolvimento de software. Tendo isso em vista, é muito importante avaliar e otimizar os elementos que favoreçam a comunicação eficaz. Contudo, na prática, existem diversas barreiras que se colocam diante do processo comunicacional efetivo. Para melhorar tal processo, é imprescindível compreender fontes de ruído que interferem diretamente na comunicação. De acordo com Chiavenato [4], existem três tipos de barreiras comunicativas: as barreiras semânticas, as barreiras físicas e as barreiras pessoais.

O esquema acima (Figura 2) ilustra o processo de ruído provocado por tais barreiras à comunicação, mostrando como uma mensagem pode sofrer interferências até chegar ao destino.

\subsubsection{Barreiras Pessoais}

Certos atos falhos na hora de ouvir e observar, envolvendo emoções e variados tipos de sentimentos, influenciam na criação de barreias pessoais. Tais hábitos baseiam-se também em crenças e percepções negativas. Por exemplo: caso uma pessoa tenha uma visão negativa dos fatos, a comunicação que ocorrerá será filtrada negativamente. O estado psicológico, emocional, também contribui como uma barreira, juntamente com o preconceito (classe social, gênero etc.).

Penteado [6] chama esses fatores de barreiras mentais: indiferença, impaciência, preconceito, preocupação. Todos estes fatores refletem diretamente durante um diálogo ou reunião, influenciando diretamente a sua eficiência 


\subsubsection{Barreiras Físicas}

A barreira física inclui o ruído que independe dos envolvidos que estão se comunicando, criando distrações. Inúmeros fatores contribuem para a distração física durante a tentativa de comunicação, podendo afetar diretamente no processo e, principalmente, no resultado esperado.

Alguns exemplos de distrações físicas são: dispositivos digitais com estímulos excessivos, chegada de pessoas no ambiente, mesa mal posta/desarrumada, assentos desconfortáveis, barulho externo, entre outros. Tais fatores que contribuem para essa distração interferem na comunicação.

Outras barreiras físicas, listadas por Penteado [6], incluem: a temperatura da sala, o ruído, a iluminação, o ambiente da sala, condições de saúde, forma de apresentação.

\subsubsection{Barreiras de Semântica}

Em linhas gerais, os problemas de semântica estão mais relacionados à linguagem empregada. A barreira da semântica acontece quando há discordância das palavras que estão sendo utilizadas e na má formação da mensagem. Às vezes, para surpreender/impressionar o receptor, a informação pode ser proferida de maneira excessivamente rebuscada e truncada, criando uma mensagem não objetiva. Nessa perspectiva, o nível de compreensão do receptor também deve ser considerado.

Esses cuidados relacionados à construção da mensagem (adequação da linguagem, escolha do vocabulário utilizado etc.) devem ser tomados no sentido de favorecer a interpretação da outra pessoa ou do grupo de pessoas envolvido. Mensagens confusas para o receptor, ou com sentido ambíguo, funcionam como ruído no processo comunicativo. A mensagem pode ser distorcida ao final ou, até mesmo, apresentada com o sentido oposto do que fora proposto inicialmente.

Além de tais questões destaca-se, também, o fato de que o processo comunicativo pode ser estabelecido entre pessoas de diferentes idiomas, com jargões, expressões idiomáticas, termos específicos de determinadas regiões etc. Todos esses aspectos podem interferir negativamente no processo comunicativo, comprometendo a sua eficácia.

\subsection{Técnicas de Comunicação}

A comunicação é uma via de mão dupla. Saber ouvir é tão importante quanto saber falar. Por tal razão a maioria das pessoas ouve tão mal ou simplesmente não ouve. Conforme Schermerhorn [8], ouvir bem é uma grande vantagem disponível a todos, inclusive aos profissionais que lidam durante grande parte do dia com a comunicação.

Um bom ouvinte observa os fatos com outros olhos e aumenta a capacidade de compreensão. Em uma conversa, ou em uma reunião, é primariamente através da audição que as informações se transformam em nossa mente e adquirimos 0 conhecimento. Um ouvinte atento conta com diversas vantagens: dispõe de melhor informação, economiza tempo, estimula a outra pessoa a falar e previne entendimentos equivocados. Uma das formas mais simples e eficientes de perceber se duas pessoas estão abertas a ouvir as ideias de outros é colocar duas pessoas frente a frente: cada um expõe seu ponto de vista e logo depois cada um repete o que o outro disse. Isso fará com que a pessoa preste atenção e escute atentamente 0 que o outro quis dizer, declara Penteado [6]. A nossa predisposição para ouvir irá deixar eficiente ou não a nossa audição.

Schermerhorn, Hunt e Osborn [8] afirmam que a ausência de feedback também atrapalha no processo e contribui como uma barreira/ruído na comunicação. Os referidos autores defendem que a ausência de feedback pode causar dificuldade à efetividade da comunicação, no sentido de que a retroação é justamente o elemento constitutivo da comunicação que proporciona saber se uma mensagem foi recebida com exatidão ou não. O feedback pode ser realizado como uma resposta à mensagem que foi enviada, por meio de um relatório, com outra mensagem, ou linguagem não- verbal.

A pragmática constitui um campo da linguística que tem nos ajudado compreender os processos da comunicação, que pode ser aplicada a Engenharia de Requisitos; assim escolhemos as máximas conversacionais por se tratar de princípios norteadores, que permite ao indivíduo, estabelecer uma comunicação eficaz, proporcionando entendimento claro deste transcurso, segundo Fiorin [7].

http: / /dx.doi.org/10.25286/repa.v2i4.845 


\subsection{Treinamento em Comunicação da Linguagem em Uso}

No processo de elicitação de requisitos, se faz necessário um treinamento focado na comunicação em uso de maneira a garantir, que haja clareza neste processo, para isso é necessário a compreensão de alguns elementos da linguagem.

De acordo com Fiorin [7], a linguagem comunica além do que aquilo expresso pelo enunciado, pois, quando se fala, comunica-se conteúdo implícito, e são esses conteúdos que podem comunicar inúmeras necessidades imprescindíveis para o desenvolvimento do software.

Para isso é necessário treinamento para entender que existe alguns elementos da linguagem como inferência a enunciação constitui parte do discurso, que traz em si importantes pistas para entendermos a necessidade do cliente, mas que sem o devido preparo passará desapercebido.

Para tanto é importante investir tempo em preparo, para que os profissionais possam desenvolver uma escuta atenta, pois agirão com mais segurança, e os resultados serão satisfatórios de ambas as partes deste processo. Portanto qualificando processo se qualificará o produto.

Para aprimorar nossa capacidade de ouvir podemos realizar atividades que ajudam a nos concentrarmos. Essas atividades podem ser realizadas até mesmo no ambiente do trabalho: tentar identificar as vozes das pessoas conhecidas e outros sons do ambiente. Também é possível realizar este exercício em qualquer outro local, basta apenas observar os sons que se repetem e tentar identificálos, diz Penteado [6]. Assim será exigido um maior nível de atenção para se distinguir os sons e consequentemente aumentar a capacidade de ouvir.

\section{Engenharia de Requisitos}

A engenharia parte da ideia de obter um conhecimento científico, com finalidade de construir, melhorar e manter os objetos relacionados em cada setor, segundo o dicionário Michaelis [9]. A Engenharia de Requisitos (ER) está contida na Engenharia de Software, responsável pela coleta de informações necessárias para o desenvolvimento do projeto. Segundo Sommerville [10], a Engenharia de 102
Requisitos é um processo que contém todas as tarefas exigidas para criar e manter os objetivos do sistema e auxiliar na obtenção de requisitos consistentes melhorando a qualidade do produto e aprimorando o processo de desenvolvimento.

Conforme Sawyer [11], Engenharia de Requisitos exige habilidades que estão ligadas com Engenharia de Software, mas também contém habilidades distintas. Por isso existe o papel de engenheiro ou analista de requisitos. Essa função não exclui o papel do engenheiro de software no desenvolvimento, entretanto enfatiza 0 papel do engenheiro de requisitos com atividades diferenciadas que intermedeiam os dois domínios: o domínio de desenvolvimento de software e o domínio de negócios.

A Engenharia de Requisitos estabelece uma base para o projeto e para sua construção. Sem ela existe uma grande probabilidade de o software não atender às expectativas dos clientes, afirma Pressman [12]. Atender os requisitos e objetivos do projeto é um dos principais pontos a caracterizar o sucesso de um software.

De acordo com Thayer e Dorfman [13], na Engenharia de Requisitos estão contidas atividades que ajudam a compreender melhor a necessidade do cliente: elicitação, análise, especificação, verificação e gerenciamento. Neste artigo abordamos apenas uma delas: a elicitação de requisitos.

\subsection{Elicitação de Requisitos}

Todas as tarefas que fornecem base para 0 desenvolvimento do software são relevantes. $\mathrm{Na}$ elicitação de requisitos não é diferente, ela possui um papel inicial muito importante, tornando mais fácil o entendimento, diminuindo as chances de ocorrer perda de tempo, retrabalho e contradição entre os requisitos, asseguram Rocha e Magalhães[14].

Contida na Engenharia de Requisitos, a elicitação de requisitos tem como objetivo primário identificar os fatos e entender quais as necessidades do usuário que deverão ser atendidas para iniciar o desenvolvimento do software, afirmam Sommerville e Kotonya [15]. A elicitação é de suma importância para a elaboração do software, pois contribui definindo os principais problemas e objetivos que o software deve resolver e permitindo a obtenção de informações mais 
detalhadas dos requisitos que darão início ao andamento do projeto. Apesar da elicitação de requisitos ser uma das primeiras atividades a ser executada, não acontece somente uma vez. Ela ocorre durante outras fases do projeto em um processo de desenvolvimento incremental, que vai sendo realizado fracionadamente, à medida que for necessario obter mais informações do cliente.

Para iniciar à elicitação devemos definir as pessoas que serão envolvidas no projeto, chamadas de stakeholders. Elas têm um importante papel durante o ciclo de vida do projeto, pois a partir das informações obtidas com eles, através de seus conhecimentos e experiências, o projeto começa a ser delineado. Os engenheiros de requisitos utilizam técnicas de elicitação para auxiliar a coleta de informações que permitam a identificação das reais necessidades do cliente. Essas técnicas colaboram na formação de uma visão mais detalhada dos requisitos do sistema, sem as quais, a identificação e construção de soluções adequadas se tornam mais complexas.

Para que se tenha uma elicitação de requisitos satisfatória, é necessário o uso de técnicas que auxiliem o entendimento e comunicação entre o engenheiro de requisitos e os stakeholders, para que as divergências sejam evitadas. De acordo com Belgamo [3], o problema da elicitação não pode ser resolvido apenas com tecnologia, mas sim com um contexto social, além de afirmar que esta etapa é mais crucial que as fases de programação e o restante do projeto. Neste trabalho abordaremos duas técnicas de elicitação: Entrevista e Brainstorming, que são duas das técnicas mais utilizadas pelos engenheiros de requisitos, para a discussão e geração de ideias criativas[3][2]. Essas técnicas foram selecionadas por fornecerem um meio de comunicação verbal entre duas ou mais pessoas e por permitirem uma maneira natural para expressar ideias e o exercício da audição. Artigo e/ou matéria de revista, boletim etc. em meio eletrônico.

\subsubsection{Entrevista}

A técnica da entrevista é fundamental para a elicitação por ser uma das formas de comunicação mais natural. É umas das técnicas simples mais utilizadas para detalhar os requisitos do software com o cliente, de acordo com Carvalho, Tavares e Castro [16]. A entrevista é uma forma de interação social, que parte da ideia de extração de informações do entrevistado e apresentá-los como fonte de referência, muito utilizada por profissionais das ciências sociais, afirma Gil [17].

$\mathrm{Na}$ execução da entrevista, o engenheiro de requisitos debate 0 assunto proposto com os stakeholders com a finalidade de compreender as necessidades dos interessados, de modo que os envolvidos colaborem com informações relativas ao tema apresentado. A partir daí, tem-se um entendimento dos requisitos do sistema.

De acordo com Sommerville e Kotonya [15] existem dois tipos de entrevista: a estruturada e não estruturada. No primeiro tipo o entrevistador, engenheiro de requisitos, tipicamente já detém um conhecimento prévio do domínio e elabora perguntas pré-definidas a fim de coletar informações para definir os requisitos do projeto. $\mathrm{Na}$ entrevista não estruturada, por sua vez, não há elaboração de um questionário prévio. Ela permite que o entrevistado discorra de modo aberto suas ideias do sistema com o engenheiro fazendo pequenas interferências pontuais.

\subsubsection{Brainstorming}

Brainstorming, ou tempestade de ideias, é uma técnica para geração de ideias, muito utilizada em dinâmicas de grupo com o objetivo de entender de forma mais ampla as necessidades dos usuários, estimulando que seus participantes desenvolvam ideias criativas alega Soares [18]. Os stakeholders são reunidos em um ambiente apropriado que encoraje a participação, permitindo que a ideias sejam expostas em voz alta para que os demais sejam influenciados e sintam-se motivados a contribuir. Essas reuniões devem ser dirigidas por um líder, o engenheiro de requisitos, que tem a função de dar início envolvendo todos os participantes e de despertar o interesse dos mesmos para que a atividade seja produtiva, conforme De Souza Rodrigues [1].

Na primeira etapa desta técnica os participantes deverão expor suas ideias sem que haja crítica ou preconceito em relação a elas. Após a finalização desta etapa dá-se início à filtragem das ideias e discussão sobre as mesmas. Entretanto se a reunião for malconduzida, e os participantes não se respeitarem, poderá ocorrer ressentimento e tensão interna entre os participantes.

\subsubsection{Entrevistas sobre entrevistas}

http: / / dx.doi.org/10.25286/repa.v2i4.845 
Essas técnicas de elicitação não são utilizadas apenas na área de Engenharia de Requisitos. Em particular, entrevistas são fundamentais em áreas como psicologia e jornalismo. Dessa forma, visando compreender mais o uso e o ensino dessa técnica em outros contextos, entrevistamos uma mestranda em jornalismo pela UFPB, bacharel em jornalismo na UNICAP, conforme transcrição a seguir:

1. Durante a formação acadêmica de jornalismo, o profissional aprende a entrevistar ou é um dom nato?

Não, não, é uma técnica. Técnicas de Reportagem é o nome da disciplina que a gente tem dentro da grade de jornalismo, mais ou menos no segundo ano e meio do curso, no quinto período, a gente estuda essa disciplina. E existem várias técnicas, de como abordar, o que perguntar... a gente sabe que tem perguntas poderosas. São aquelas perguntas que vão fazer com que o nosso entrevistado fale aquilo que a gente precisa saber. Então a gente aprende toda uma técnica de perguntas: a gente faz um roteiro de perguntas, claro que esse roteiro ele não é fechado, a gente pode alterar algumas coisas na hora mesmo da entrevista. Algumas perguntas podem subir, podem ser descartadas, de acordo com o andamento do processo. Mas não é nada de dom não, é muito estudo, pelo contrário.

2. No âmbito acadêmico são estudadas técnicas para melhorar as reuniões em grupo?

Sim, sim a gente também tem condução, "né" de reuniões. Não é muito o foco do jornalismo. A gente prepara mais os alunos meio que pra o mercado pra fazerem matérias, entrevistarem. Mas a gente pode também é... No caso o passo a passo é mais ou menos assim: primeiro a gente estuda sobre o assunto, sobre a pessoa que a gente vai entrevistar, sobre o conteúdo. A gente tenta reunir o máximo de informações que a gente possa ter em um curto período de tempo de quinze minutos, mais ou menos. Mas claro que dependendo da matéria, tem matérias que a gente consegue um tempo maior, um dia, dois dias, mas isso são cada vez mais raros. Quando a gente está em redação a gente recebe uma folha de pauta, que nesta folha de pauta já vem as principais informações. Quando a gente vai pra campo, vai pra rua fazer a matéria, a gente já sabe mais ou menos o que está acontecendo. $\mathrm{E}$ aí depois a gente começa a elaborar as perguntas a partir daquilo. Normalmente a gente faz um roteiro de uma entrevista comum, cinco a seis perguntas.

3. Para realizar uma entrevista, durante a faculdade, são estudadas e aplicadas algumas técnicas? Que técnicas?

Entendi. A gente tem várias. Cada pessoa tem um feeling, ele sente o momento apropriado em fazer determinada pergunta ou não. O que é que acontece? É muito comum hoje, porque o mundo está muito corrido, está todo mundo muito acelerado, não ter tantas entrevistas como antes presenciais. Porque nas entrevistas presenciais a gente consegue sentir mais o outro, a gente consegue saber se a pessoa está querendo fugir da pergunta, se a pessoa está desconfortável, se a pessoa está mentindo. "Né? " Existem algumas técnicas de neurolinguística que a gente consegue perceber quando o outro está querendo desviar do objetivo da pergunta. Mas não é muito comum a gente fazer entrevistas pessoalmente é mais por telefone ou então por e-mail e até por WhatsApp. "Né"? Então, o que é que acontece? Nisso a gente perde alguns elementos da comunicação não verbal. A gente não consegue ter esse feeling. Claro, que se a gente entender e conviver muito com o outro, a gente vai perceber pelo timbre vocal, se está falando certo ou não. Mas perdem outros elementos. Então assim, na graduação a gente incentiva os alunos a eles sempre estarem fazendo entrevistas pessoalmente para irem aprendendo. Mas com o passar do tempo a gente acaba utilizando outras plataformas, utilizando WhatsApp, Facebook, e-mail, telefone, áudio por WhatsApp e por aí vai. Vídeo conferência também. Pelo Messenger, que a conexão é mais segura, segura mais.

Hoje se adota mais já, essa entrevista pelo meio digital? É maior que a presencial?

Sim, bastante. Infelizmente sim. Claro, que quando são grandes reportagens, materiais mais amplos que precisam um trabalho maior de tempo, a gente faz pessoalmente. Mas a grande maioria é tudo digital. Tudo no meio físico.

4. Existe alguma técnica para concentração e/ou despertar interesse em ouvir?

Sim. A principal questão é você gostar de pessoas. Porque se você gosta de seres humanos naturalmente você vai desenvolver empatia, independentemente de ser uma pessoa estranha. Só que você não está agindo com seu contato. Então, o que é que acontece? 
Você acaba começando a conversar, querendo saber... A dica sempre é: ter interesse pelo outro. Hoje em dia a gente está querendo muito contar a nossa história, nossa história de vida. Entendeu? O que a gente está vivendo, o que a gente está passando. E quer ouvir pouco o que o outro está vivendo, que o outro está passando. Então quando eu gero interesse pelo outro, eu consigo cativá-lo. E aí quando eu consigo cativá-lo, eu consigo fazer com que ele dance. É como se fosse uma música, a entrevista, sendo que quem está ditando o passo é o entrevistador. E aí a gente enquanto jornalista, a gente tenta fazer com que o entrevistado entre na dança junto com a gente. Ele entre no assunto com a gente pra a gente poder chegar com a matéria pra sociedade, pra dar um serviço público. Então quando a matéria é mais tranquila, no sentido de é uma matéria de bem-estar e qualidade da vida, é "mamão com açúcar". Todo mundo quer participar, todo mundo quer se posicionar, todo mundo quer falar. Mas quando é um assunto mais delicado: tipo política! Nem todo mundo quer se posicionar, nem todo mundo quer falar. Então a gente... existem fontes jornalísticas, são pessoas, que normalmente são as pessoas que já dão entrevistas em jornais, em rádios e TVs, que são pessoas já estão costumadas a fazer isso e são pessoas disponíveis. A agenda do jornalista é uma agenda muito curta, então as vezes ele quer fazer uma entrevista, mas a pessoa nunca foi entrevistada. Então não tem aquela disponibilidade, ou então só quer presencial, e o jornalista não tem disponibilidade de ir. Então assim, pra evitar esses, esses ajustes, que as vezes a gente não consegue fazer, a gente costuma ter uma fonte jornalística, que é uma pessoa gabaritada pra responder sobre aquilo. Então, quando a gente tem um caderno de fontes, todo jornalista tem, então quando a gente já tem nossas fontes, já pra um determinado assunto, a gente... é natural recorrer sempre a elas. Não ficar mudando muito.

5. Como são tratados os ruídos que interferem durante a entrevista e reuniões? Algum método adotado para evitá-los?

Sim, tem alguns detalhes técnicos, "né"? Por exemplo: a gente nunca vai gravar na contraluz ou tirar foto na contraluz. Não vai funcionar, "né"? A gente também tem que ver o em torno, como é que está o ruído do ambiente. Se estiver num lugar muito barulhento, se o ar-condicionado está fazendo barulho, se tem equipamento eletrônico ligado, se o celular está tocando e no silencioso. Porque se chega mensagem no WhatsApp a cada um segundo, "né"? Então assim, tem alguns cuidados que a gente tem que ter de preservação mesmo do material que vai ser produzido. Mas em linhas gerais, o que a gente precisa é focar atenção no outro. A nossa sociedade está cada vez mais tão acelerada que a gente não consegue perceber o outro. E aí quando a gente está com comunicação e a gente foca no outro, foca naquela comunicação, foca naquele momento, toda nossa atenção ela deixa de ser desviada para outros meios e fica naquele tempo de espaço e então a gente consegue um resultado muito maior. Acontece que a gente vai para as reuniões de trabalho, mas está pensando: "Poxa, reunião no meio do expediente, não vou conseguir entregar aquele relatório", ou então "poxa, reunião no meio do expediente, mas logo agora que eu queria fazer outra coisa", ou seja você está ali naquele momento... a preocupação é com outra coisa externa que influencia e interfere na reunião. Exatamente. A dica é: foque no momento presente. Para isso tem vários livros que ensinam técnicas de meditação, de concentração pra você estar focado naquele momento.

Uma técnica simples, que é uma técnica oriental que eu gosto muito, que eu ensino aos meus alunos em sala é o tratak, que é bem simples. Você desenha um círculo, normal, não precisa ser bom de matemática, e no meio você desenha um ponto, só um ponto. O exercício é você focar no ponto. Você vai focar tanto no ponto até que a borda do círculo desapareça de sua visão. Até isso acontecer, significa que você está focado no meio presente. Ou seja, você não está sendo desviado por nenhum pensamento e por nada que esteja acontecendo naquele momento. E aí quando você consegue-se fazer o exercício e consegue aumentar o tempo em que você consegue não enxergar a borda do círculo, você consegue ter um maior poder sobre a mente. Porque hoje em dia o que se mais pauta, puxando pra o ser humano, não pé nada fora, é consigo mesmo. É você conseguir controlar os seus pensamentos, controlar a mente, controlar a própria ansiedade, e aí tudo isso, esse exercício acaba ajudando e muito.

6. Existem maneiras em treinar o entrevistado a falar somente o indispensável e ser objetivo?

A gente tem alguns cursos. A gente tem um curso chamado media training, que a gente ensina grandes líderes, grandes empresários, gestores a falar com a imprensa. Então a gente tem media training para rádio, media training para $\mathrm{TV}$, media training para impresso. Porque cada um desses veículos de comunicação possui características diferentes. E a gente precisa entender cada característica pra poder responder da melhor forma. Então assim, uma pessoa http: / / dx.doi.org/10.25286/repa.v2i4.845 
que ela é muito solicitada pra estar na mídia, pra estar dando entrevista, normalmente a gente indica esses cursos de media traning porque a pessoa fica "mais fácil", ela não fica tão nervosa, sabe, e se sente mais tranquila no processo. Mas aí se a pessoa não pode fazer um curso o que é que faz? Deixa o jornalista conduzir. Responda o jornalista, mas não é aquela resposta assim: "não", "talvez", "não sei", sabe, jornalista tem uma aflição quando tem essas respostas. Responda ao jornalista assim, de uma forma mais solta, como se fosse um amigo. Mas não se desviar muito da conversa, porque também tem gente que quando se sente amigo quer falar da vida toda, "né"? Então assim, tentar ter um equilíbrio do que vai falar. Normalmente antes das entrevistas o jornalista sempre conversa com a fonte. Sempre conta pra ela qual o objetivo da matéria, qual o caderno que vai ser vinculado, qual o jornal, qual veículo. Porque assim a pessoa tem uma ideia de mais ou menos pra que caminho vai seguir.

7. As reuniões presenciais são mais produtivas que as digitais?

Depende muito do perfil das pessoas, nesse mundo que a gente está com muita gente da geração " $Z$ " e " $Y$ " entrando no mercado de trabalho, que são as pessoas mais antenadas, então assim é natural eles produzirem mais pelo meio digital. Porém é muito do perfil da empresa, do serviço. É, empresas mais tradicionalistas fica mais difícil adotar essa nova ferramenta de comunicação. Mas empresas mais jovens, mais arrojadas é mais tranquilo. Até porque o funcionário reflete muito o pensamento corporativo, então se é muito da gestão, é muito das pessoas, mas em nível de produtividade é da pessoa. Não tanto assim da empresa, nem de quem está conduzindo, de quem está participando. Porque as vezes, eles podem pegar uma reunião de negócios e entrar vários assuntos paralelos que não estavam na pauta e desfocar totalmente. Então é muito da forma de como está sendo gerenciado o processo.

8. Em questão do ambiente (mal arrumado, iluminação e poltronas desconfortáveis) que será realizada a entrevista ou reunião em grupo, influencia em algum aspecto?

Sim, tem isso também. Tem uma técnica chamada Feng Shui, que é uma técnica oriental também, que ela trabalha a organização do ambiente, tanto o ambiente empresarial como casa também. Pra que você possa ter um ambiente mais favorável ao crescimento, ao desenvolvimento humano. Tem isso. Mas o que também acontece bastante, as pessoas acabam optando por determinadas carreiras, não por questão de vocação, mas por questão de escolha por salário, de oportunidade e por aí vai. Quando a gente está muito concentrado no ambiente, ou seja, quando consegue-se atingir nosso nível de flowing, que quando a gente... o que estiver acontecendo aqui externamente não impacta na minha produção, porque eu estou tão focada no meu resultado, no meu projeto, que pode estar chovendo lá fora, porque vou estar prestando atenção. A gente percebe isso quando a gente passa muitas horas e não percebeu que 0 tempo passou. São momentos que a gente consegue ter dedicação exclusiva naquele momento, e possivelmente isso está cada vez mais raro, "né"? O tempo todo a gente fica olhando para o celular pra ver, nossa ainda falta isso tudo de tempo. Então, a gente está cada vez mais distante desse momento de flowing, que é quando a gente consegue atingir o processo criativo mais pleno, a gente consegue atingir o nosso maior potencial humano. E é nesse momento independe se a sala está quente ou se está muito fria, independe se você está com fome e você acabou de lanchar, independe se a sala está com muito barulho, ou então com muito silêncio. Porque você está muito focado naquilo que tem que entregar.

Caso não haja essa concentração, estes outros fatores interferem na produtividade? Isso, bastante na produtividade. Você fica com baixa produtividade, não consegue se concentrar, não consegue ter ideias, não consegue finalizar as atividades, fica mudando de uma atividade para outra. Como uma olhadinha na internet, saindo de uma página para outra e não consegue ter atenção em uma coisa só.

\section{Análise das Técnicas}

Nesta seção é apresentada uma análise de duas técnicas de elicitação de requisitos: Entrevista e Brainstorming. Essa análise baseia-se nos conceitos, nas barreiras, e nas técnicas de comunicações, conforme introduzido na seção 4. Após a análise sucinta de cada técnica, são apresentados pontos em comum a ambas e considerações gerais.

\subsection{Análise: Entrevista}


Durante a execução de uma Entrevista ocorre frequentemente a variação de posições entre os papéis de emissor e de receptor, pelos engenheiros de requisitos e os demais stakeholders. Ou seja, ocorre uma alternância entre quem está falando e ouvindo em determinado momento. Eles revezando os papéis a partir do instante em que utilizam o canal da comunicação, neste caso a fala, quando cada um por sua vez é solicitado.

As máximas conversacionais, de acordo com Fiorin [7], constituem princípio norteador que cooperam com a comunicação, e por isso são imprescindíveis no processo da entrevista, pois permitem que a comunicação flua de maneira que as partes possam obter o maior resultado desta interação. Sabemos, contudo, que essas trocas verbais nem sempre são harmoniosas, mas dentro da entrevista é necessário que $o$ entrevistador se esforce para explorar as máximas de maneira que haja uma fluidez das ideias.

Podemos exemplificar através da máxima de quantidade que trata o excesso de informações desnecessário sobre a pena de interferir no processo da entrevista através da indução dos resultados. Dentre a máxima de qualidade, a afirmação de informações não consistentes deve ser evitada sobre a pena de ter sua entrevista desqualificada, pois trará dúvidas sobre a processo. A pertinência é uma máxima que deve ser observada com rigor, pois a não observância trará perda de tempo, além desvios do objetivo proposto. A clareza deve ser um dos primeiros princípios a ser aplicada na entrevista, pois manterá a entrevista dentro do foco proposto, permitindo respostas precisas de maneira que colabore com desenvolvimento da técnica.

\subsection{Análise: Brainstorming}

Essa técnica de discussão em grupo permite que cada um possa contribuir, espontaneamente, apresentando novos conceitos para resolver o problema apresentado na discussão.

Como já sabemos que a escolha dos stakeholders deve ser um trabalho bem realizado, alguns problemas pessoais devem ser observados para que não haja problemas.

Durante o Brainstorming as ideias vão surgindo e o ideal é que todas as ideias expostas sejam aproveitadas e não sejam criticadas pelos componentes. Sendo assim, é importante atentar-se para barreiras pessoais que possam prejudicar a sessão de Brainstorming. A impaciência por não ter tempo para ouvir, por não estar de acordo com o que a outra pessoa fala, ou a preocupação com algo que não condiz ao assunto abordado gera desconcentração e dificuldade de compreensão da reunião. No mesmo cenário está a indiferença, um ouvinte desinteressado não ouve devidamente o que está sendo exposto. $O$ preconceito também interfere durante reunião, quando achamos que já sabemos do assunto abordado ou quando selecionamos para ouvir apenas aquilo com que concordamos. Essas barreiras pessoais têm o potencial de prejudicar a efetividade da elicitação durante a aplicação da técnica e acaba criando ruído e filtrando ou até mesmo bloqueando as mensagens.

Em momentos de apresentação, esta deve ser feita de forma atrativa e dinâmica para que desperte interesse individual dos participantes, pois o ouvinte desinteressado a ouvir cria barreiras e não mostra atenção pelo assunto abordado. Por outro lado, devese despertar interesse próprio ao ouvir.

\subsection{Considerações gerais}

A extração dos requisitos é indispensável para o desenvolvimento do sistema. É necessário então que se tome medidas visando reduzir as barreiras encontradas na elicitação dos requisitos. Além do engenheiro de requisitos ter o conhecimento de como identificar suas próprias barreiras, como já mencionado anteriormente, ele precisa ser proativo de forma a estimular os envolvidos na elicitação.

$\mathrm{Na}$ realização das técnicas de Entrevista e Brainstorming, o engenheiro de requisitos deve levar em conta de que fatores físicos atingem diretamente na extração das informações, podendo prejudicar na concentração e na audição dos envolvidos. É preciso preparar o ambiente de reunião para que o resultado seja satisfatório. A sala deve ser isolada dos demais ambientes para que não haja interferências, tal como barulho externo. Deve considerar também a temperatura da sala em que será aplicada a técnica, pois tanto 0 frio quanto o calor excessivo desconcentram, causando irritabilidade dos participantes. O ideal é que a sala esteja em uma temperatura agradável. O mesmo acontece com a iluminação, que deve estar de forma balanceada visto que muita luz ou pouca luz causam perturbação do indivíduo e impedem a concentração. Um bom ambiente favorável apresenta uma boa acústica, ajudando na audição, como os auditórios, igrejas e http://dx.doi.org/10.25286/repa.v2i4.845 
cinemas, que são projetados para que o nível de atenção seja intenso. Ainda nesta sala, leva-se em conta as poltronas que devem ser confortáveis para que não crie irritação e, consequentemente, a perda da concentração.

A saúde do participante é um outro fator relevante. Se um stakeholder não estiver apto para aquele momento haverá indisposição física, prejudicando o nível de concentração e de audição.

Para se manter concentrado e ouvir melhor o indivíduo deve evitar distrações durante a reunião, estar disposto ter tempo para ouvir, não apoiar a cabeça, nem o corpo para ouvir e ficar sempre em uma postura firme para ouvir e também observar cada fator físico e mental que possam influenciar na concentração para falar e ouvir.

A atenção a esses fatores vai além do que é comumente prescrito em livros-texto de Engenharia de Requisitos, que focam no passo-a-passo para aplicação das técnicas de elicitação. Sendo assim, hipotetizamos que o estudo e a análise de conceitos e técnicas de comunicação por parte dos engenheiros de requisitos sejam benéficos para o resultado da elicitação de requisitos, uma vez que pode habilitá-los a identificar os problemas e aplicar as práticas e técnicas adequadas para melhor extração dos requisitos.

\subsection{Conclusão e Trabalhos Futuros}

Durante a realização deste estudo foi observado que a comunicação interpessoal não é amplamente abordada no âmbito da literatura acadêmica em Engenharia de Requisitos no Brasil, sendo mais frequente nas áreas de Linguística, Psicologia, Sociologia e Administração. Esse dado chama a atenção, tendo em vista a importância da comunicação para a Engenharia de Requisitos demonstrada durante o desenvolvimento do artigo, subseção 3 e seção 4.1. A comunicação eficaz requer que algumas atividades sejam cumpridas, além da ação comunicativa em si.

No que diz respeito às técnicas, que contribuem para o sucesso da elicitação: na comunicação, foi observado que existem técnicas para aprimoramento e favorecimento da concentração, estimulando interesse e melhorando a audição. Já no que se refere à importância da comunicação nos projetos de software, coloca-se a relevância dos processos comunicativos para a eficácia do projeto no âmbito da Engenharia de Requisitos - ainda que seja uma área geralmente ainda não considerada com a devida importância.

Por fim, os problemas causados por falhas na comunicação na elicitação podem causar conflitos na equipe e trazer também outros tipos de prejuízos, tais como retrabalho, perda de tempo, aumentos dos custos, estresse da equipe.

Diante do encontrado, acreditamos que a comunicação ocupa papel fundamental durante todo a elicitação de requisitos para desenvolvimento de um software. Mesmo assim, os processos comunicativos nem sempre são plenamente valorizados, o que pode compromete a eficácia da elicitação, em virtude dos ruídos na comunicação.

Este é um trabalho preliminar, que visa iniciar uma série de estudos sobre comunicação e como seus conceitos e técnicas podem ser aplicados para aperfeiçoar as atividades de Engenharia de Requisitos. Continuando ainda nesta temática, para um futuro estudo, será investigado como, na prática, a comunicação na elicitação de requisitos se dá em empresas que desenvolvem softwares. Bem como a análise do nível de importância que se atribui no interior dessas empresas à comunicação e quais impactos as falhas de comunicação podem trazer para a empresa.

\section{Referências}

[1] DE SOUZA RODRIGUES, Débora - A Importância do Uso das Técnicas de Extração de Requisitos para o Desenvolvimento de Softwares - Três Lagoas

[2] PENTEADO, Whitaker J. R. - A Técnica Da Comunicação Humana - 10. Ed - Editora Pioneira, 1987.

[3] BELGAMO, Anderson, EDUARDO, Luiz, MAR- TINS, Luiz Eduardo - Estudo Comparativo Sobre as Técnicas de Elicitação de Requisitos do Software. Artigo - UNIMEP - Campus Taquaral Piracicaba - SP, 2008.

[4] CHIAVENATO, Idalberto. Comportamento Organizacional: a dinâmica do sucesso das organizações. 2. Ed. - Editora Elsevier Rio de Janeiro - RJ, 2005. 
[5] MONTEIRO, Alexsandra; ALENCAR, Luciana Hazin. Análise dos problemas de comunicação em projetos de desenvolvimento de Software. XXVII Encontro Nacional de Engenharia de Produção (EN- GEP). Foz do Iguaçu - PR, 2007. [6] PENTEADO, Whitaker J. R. - A Técnica Da Comunicação Humana - 10. Ed - Editora Pioneira, 1987.

[7] FIORIN, José Luiz - Introdução à Linguística: objetos teóricos- Editora Contexto São Paulo -SP, 2010.

[8] SCHERMERHORN, John R. Jr., HUNT, James G., OSBORN, Richard N. - Fundamentos de Comportamento Organizacional. 2. Ed. - Editora Bookman - Porto Alegre - RS, 2002.

[9] DICIONÁRIO MICHAELIS - Disponível em: <http://michaelis.uol.com.br/busca? $\mathrm{r}=0 \& \mathrm{f}=0 \& \mathrm{t}=$ 0\&palavra=engenharia $>$ Acesso: 25/05/2017.

[10] SOMMERVILLE, Ian - Engenharia de software - $6^{\mathrm{a}}$ Ed. - Pearson Education - São Paulo - SP - 2003.

[11] SAWYER, Pete - Software Requirements Engineering - An Introduction and Overview Disponível:

<http://sce.uhcl.edu/helm/REQ_ENG_WEB/MyFiles/mod1/swreqinto/SREngineering.htm>

Acesso: 17/05/2017.

[12] PRESSMAN, Roger S - Engenharia de software, uma abordagem profissional - 8a Ed AMGH Editora Ltda. - Porto Alegre - RS - 2016.

[13] THAYER, R. H. e DORFMAN, M Introduction to Tutorial software Requirements Enginnering in Software Requirements Engineering, IEEE-CS Press, Second Edition, 1997.

[14] ROCHA, Rafael da Silva, MAGALHÃES, Terezinha Moreira - Engenharia de Requisitos Revista Eletrônica - Fundação Educacional São José - 4a Ed. Santos Dumont - MG, 2015.

[15] SOMMERVILLE, Ian e KOTONYA, Gerald Requirements Engineering, processes and techniques - $1^{\text {a }}$ Ed - Editora: John. Wiley \& Sons Ltd - England -1998.

[16] CARVALHO, Ana E.S, TAVARES, Helena C.T , CASTRO, Jaelson B. Uma Estratégia para Implantação de uma Gerência de Requisitos visando a Melhoria dos Processos de Software. WER01. Buenos Aires, Argentina, 2001.

[17] GIL, Antonio Carlos - Métodos e Técnicas de Pesquisa Social - 6a Ed - Editora Atlas - São Paulo - SP, 2010

[18] SOARES, Emiliane Silva SWREQUIREMENT: Uma Proposta de Integração de Técnicas de Elicitação de Requisitos ao Processo de Levantamento e Análise de Requisitos. UFLA, Minas Gerais, 2007. 